\title{
I Do, We Do, You Do Home Economics: Explicit Instruction Connecting Content with Ideology
}

JAY R. DEAGON ${ }^{1}$

$\approx$ Explicit instruction is a teaching model that demonstrates to students what to do and how to do it. One purpose of ideology is to focus the who, what, when, where, and why of a disciplinary field. Trained home economists make a sustained commitment to the core ideology of home economics. Mechanisms for identifying locally relevant challenges faced by individuals, families, and communities are embedded in the home economics knowledge base. To identify challenges and locate solutions (who, what, when, where, and how), home economics education programmes must actively teach or provide explicit instruction about the ideology that underpins the home economics disciplinary field. Neglecting ideology results in teaching unrelated subjects or compartmentalised content that may dilute connection to the core aims of the home economics' 'big picture. This paper outlines how explicit instruction and embedded home economics ideology have positively impacted perceptions of the discipline amongst professionals who are new to the field. In teaching and learning environments, making home economics ideology visible and reinforced continuously across all content specialisation areas, the author observed that students acquired the words and concepts to explain the importance of home economics to others. Professionals who are new to the field became more confident and passionate advocates for home economics, because they had learnt and appreciated, through explicit instruction techniques, the what, the how to, and the why of home economics. Equipped with the discipline's core ideology, professionals who make visible the home economics 'big picture' (i.e., the why) to others are better equipped to enact real-world applications of home economics that can adapt continuously to meet ever-changing and complex societal needs.

Keywords: home economics, explicit instruction, ideology, professional practice

1 College of Education, School of Education and the Arts, Central Queensland University, Australia; j.deagon@cqu.edu.au. 


\section{Jaz gospodinjim, mi gospodinjimo, ti gospodinjiš: eksplicitno poučevanje, ki povezuje vsebino $\mathrm{z}$ ideologijo}

JAY R. DEAGON

$\propto$ Eksplicitno poučevanje je model poučevanja, ki učencem pokaže, kaj in kako naj nekaj naredijo. Eden izmed namenov ideologije je tudi, da se za posamezno disciplinarno področje osredotoči na iskanje odgovorov na vprašanja kdo, kaj, kdaj, kje in zakaj. Usposobljeni strokovnjaki gospodinjstva se tako trajno zavežejo temeljni ideologiji gospodinjstva. Mehanizmi za prepoznavanje lokalno pomembnih izzivov, s katerimi se spoprijemajo posamezniki, družine in skupnosti, so vgrajeni v temeljno bazo znanja gospodinjstva. Za prepoznavanje izzivov in iskanje rešitev (kdo, kaj, kdaj, kje in kako) morajo izobraževalni programi gospodinjstva aktivno poučevati ali zagotavljati jasna navodila glede ideologije, ki predstavlja temelj disciplinarnega področja gospodinjstva. Zanemarjanje ideologije ima za posledico poučevanje nepovezanih tem predmetov ali razdrobljenih vsebin, kar lahko oslabi povezanost s temeljnimi cilji »širšega smisla» gospodinjstva. V tem prispevku je opisano, kako eksplicitno poučevanje in temeljna ideologija gospodinjstva pozitivno vplivata na dojemanje discipline med novimi strokovnjaki tega področja. Opazili smo lahko, da so študentje v učnih okoljih, v katerih je ideologija gospodinjstva izpostavljena in se nenehno krepi oziroma poudarja na vseh vsebinskih strokovnih področjih, usvojili besede in pojme, s katerimi lahko drugim razložijo pomen gospodinjstva. Strokovnjaki, ki so bili na tem področju novi, so postali samozavestnejši in bolj zavzeti zagovorniki gospodinjstva, saj so se s pomočjo eksplicitnega poučevanja naučili in spoznali pravo vrednost koncepta, kaj, kako in zakaj gospodinjstvo. Strokovnjaki, ki so opremljeni s temeljno ideologijo stroke in ki drugim približajo »širši smisel « gospodinjstva (tj. zakaj), so bolje opremljeni za uvajanje realnih, življenjskih zahtev/izzivov gospodinjstva, da se lahko vseskozi prilagajajo nenehno spreminjajočim se in kompleksnim družbenim potrebam.

Ključne besede: gospodinjstvo, eksplicitni pouk, ideologija, strokovna praksa 


\section{Introduction}

Public perceptions of home economics are, stereotypically, that students learn cooking and sewing at school (Deagon, 2012), but home economics is more multifaceted than that simplistic idea. Formally trained home economists understand the complex and interwoven social, cultural, physical, mental, spiritual, and environmental health and wellbeing outcome ramifications that apply to learning beyond the action of learning how to cook and sew. The what and how of home economics may be 'cooking and sewing'; however, when teaching and learning in the field, the ideology of the professional must also explicitly include the why we are teaching and learning and pedagogy of how we teach it. This paper will advocate for home economics as a holistic subject that contributes to complex issues through practical life skill education. The context of this paper is within the training of home economics teachers in higher education.

\section{Education Sector Context and Nomenclature}

As professionals, home economists work in numerous fields, including teaching and academia, with industry, in service organisations and governments, as nutritionists, early childhood educators, in the textiles and fashion industries, hospitality and other health and community-related services (International Federation for Home Economics (IFHE), 2008). The work that home economists are best known for is within two education sectors: secondary schools (teaching) and higher education (academia). Contrary to a report from McCloat and Caraher (2020) that home economics undergraduate degrees are only available to Australians wishing to upskill into home economics via a graduate diploma in Victoria, the Queensland University, through which the author of the present paper is employed, offers several options. People from all over Australia can, and do, undertake a nationally accredited undergraduate Bachelor of Education degree specialising in home economics; tradespeople and post-graduates may gain a teaching qualification via multiple pathways, and registered teachers may undertake a Diploma to add Home Economics as a teaching specialisation. Additionally, Canada, Ireland, and Malta have recently introduced online Masters programmes, and $\mathrm{PhD}$ candidates who wish to study in the field of home economics can locate appropriately qualified home economics specialist supervisors in many universities around the world. Statistics regarding numbers and pathways of enrolments into these higher education programmes, nationally or internationally, were not available at the time of writing. 
From the author's experience, undergraduates and qualified teachers training into the field of home economics are learning the same content and ideology together in the same classes. Therefore, there is a reluctance to name these students as pre-service teachers. In this paper, further reference to these combined cohorts of higher education students will be 'new-to-the-field professionals'

\section{Reasons for Learning Home Economics in the $21^{\text {st }}$ Century}

As previously suggested, cooking and sewing is a narrow view; however, to make the point explicit, I will use the cooking and sewing axiom of home economics to argue the next section of this paper. There are many practical and purposeful reasons to learn how to cook or sew. In addition, the attraction to teaching home economics is various. The contributions of home economics to the middle years of schooling (typically adolescents aged between 12 to 15 years) are multidimensional. The structure and content of home economics curricula around the world are derived from local and/or national curriculum priorities (Deagon, 2015a; McCloat \& Caraher, 2020); however, they are influenced by comparatively similar ideologies.

At the international level, home economics has a clear and explicit focus 'to achieve optimal and sustainable health and wellbeing of individuals, families and communities' (IFHE, 2008). Home and family are the cornerstones of society. Everything that happens in a home and within a family radiates into the world. Home economists recognise complex transactions between home/ family and 'the world' and provide individuals, families, and communities with mechanisms to make informed decisions that may improve their quality of life (Nickols \& Kay, 2015). Home economics offers a 'kaleidoscope' of skills and knowledges (Nickols et al., 2009) that are complex and multifaceted, in which trained professionals recontextualise and reproduce interpreted content (Deagon, 2015a) for the location within which it is being taught and learnt.

Study within the home economics discipline takes holistic, systems, and/or ecological approaches to curricula in which topics can include the study of food and nutrition, textiles and fashion design, financial literacy, family relationships, childhood development, and community empowerment (Darling \& Turkki, 2009; IFHE, 2008; McGregor, 2011; Nickols et al., 2010; Turkki, 2012). Each topic then has embedded aspects of technology use, ethics, environmental sustainability, design thinking, problem-solving, and service to the community (Dislere et al., 2020; Erjavšek et al., 2020; Gentzler, 2012; Ronto et al., 2017a). Home economics is a complexity-driven, authentic, and applied discipline that 
connects 'real world' activities and actions with people's everyday lives, wherever they may live. When asked, most new-to-the-field professionals will relate that their reason for becoming a home economics teacher is their passion and desire (Sewell, 2008) to make a positive difference in the lives of children and their families and to teach important life skills.

\section{Too many cooks, not enough teachers}

'Teaching' people cooking has become ubiquitous. There are millions of 'how-to' videos on television, websites, and social media. A decade ago, Cunningham-Sabo and Simons (2012) recognised there was an issue with too many cooking shows and, despite this, too few people know how to cook. Cookery classes occur in a myriad of classrooms and kitchens around the world each day. Home economists do a portion of this work, but many of the cooking instructional videos are made by cooks, chefs, or self-confessed 'foodies'. The key difference between a cookery class conducted by a chef and a home economist is the teacher's underpinning reason for teaching cooking. A social media 'foodie' demonstrates a recipe. A home economist teaches a recipe and simultaneously includes explicit instruction of skills, nutrition information, hygiene, and safety. This means that a particular ideology directs a cooking teacher (personal or professionally informed), but not all skillsets are equal or adequate. The ideology informs the why or the purpose of teaching cooking to a target audience. Thinking critically, the instructor's skillset and pedagogical approach must be examined in relation to by what means (how) they are teaching cookery. Home economics education programmes combine ideology with skills, knowledge, and pedagogy: this is powerful and unique to the profession.

Correspondingly, a student seeking to learn cookery may either want a job in the hospitality industry or learn how to become independent when they leave home. These two reasons for wanting to learn how to cook are quite different. The content (knife skills, food safety, recipe interpretation, sensory evaluation) is the same; the why is different. Alternatively, a cooking teacher may want to inspire a new generation of chefs or, perhaps, influence healthy eating behaviours. Again, the content (knife skills, food safety, recipe interpretation, sensory evaluation) is the same; the why is different. This same process of teaching home economics-related content to people occurs across other content areas, such as financial literacy, textiles and fashion design, craft, early childhood, and so forth, where the difference in teaching hinges on the foundational why the subject is being taught or wanting to be learnt. For these reasons, the ideological and philosophical exchange between teacher and learner is an important transaction. 
Higher education students of home economics need to acquire specific knowledge and skills to be considered proficient in certain knowledge areas and meet professional accreditation requirements. The role of the lecturer in explicit instruction is key. New-to-the-field professionals need to become acquainted with the core ideology of the profession to ensure that new-to-thefield professionals are empowered to enact the 'best practices' of the profession. Ideology focuses the who, what, when, where, and why of a disciplinary field. The ideology of the instructor and learner must complement pedagogy for a purposeful exchange of knowledge and skills to occur.

\section{Explicit Instruction as a Teaching Tool}

In this paper, explicit instruction means clearly stating, in detail, so as to leave no room for confusion or doubt, details about how a concept should be done. Explicit instruction is a teaching model that demonstrates to students what to do and how to do it. Historically, explicit instruction is employed with younger children (Kruit et al., 2018), with students learning to write and speak languages (Graham et al., 2013) or with students who live with learning disabilities (Hall-Mills \& Marante, 2020). Interestingly, van de Kamp et al. (2015) conducted a small scale study with 147 secondary school students in visual arts education and found that explicit instruction was very useful to reinforce metacognitive divergent higher-order thinking skills and knowledge, while direct instruction impeded originality and creativity. Similarly, Ashman et al. (2020) reported that explicit instruction was useful for predicating problem-solving activities. Despite the typical uses for employing explicit instruction, the concept of explicitly demonstrating to students a particular concept is effective with any age group of learners. Explicit instruction can set the prerequisite declarative knowledge required to move toward procedural knowledge, creative, entrepreneurial, and original thinking and action.

In its simplest form, a teacher may use explicit instruction in an I Do - We Do - You Do structure to scaffold a learning activity. First, the teacher models the activity. Second, a structured learning activity is completed as a group learning activity. Third, individual students enact the activity without initial support and then receive peer and teacher feedback. A recent monograph by Dislere et al. (2020), Home Economics colleagues from Latvia, used didactic teaching tools and methods in a similar way to explicit instruction to make connections between Information Communication Technologies (ICTs) and quality of life. In their study, concrete concepts of home economics were the vehicle through which natural, economic, social, and political environments were linked with 
wellbeing, happiness, and life satisfaction. The key factor for educators is to make explicit connections for students between concrete concepts (the what and how skills and knowledge) and ideology (the why we are learning this concept).

\section{Suggestions for Explicit Instruction in Home Economics}

This paper considers explicit instruction to be an empowering and transformative education tool and follows Pendergasts' Home Economics Literacy Model (HELM) (Pendergast \& Deagon, 2021). HELM is useful for informing the parameters of transformative action and best practices in home economics. Table 1 gives examples of explicit instruction used by a home economics lecturer with new-to-the-field professionals and demonstrates the author's practical application of explicit instruction with her students. The suggestions offer desirable progression and outcomes for students to become independent, passionate and confident home economists. The author was similarly inspired by her contemporaries.

\section{Table 1}

Examples of explicit instruction used by a home economics lecturer with new-tothe-field professionals

\begin{tabular}{|c|c|c|}
\hline $\begin{array}{l}\text { I Do } \\
\text { (Lecturer) }\end{array}$ & $\begin{array}{l}\text { We Do } \\
\text { (Lecturer and Students) }\end{array}$ & $\begin{array}{l}\text { You Do } \\
\text { (Students) }\end{array}$ \\
\hline $\begin{array}{l}\text { Role model active participation in } \\
\text { local, national and international } \\
\text { Home Economics association } \\
\text { activities. }\end{array}$ & $\begin{array}{l}\text { Facilitated practical } \\
\text { residential schools that } \\
\text { incorporate peer learning } \\
\text { of ideology, skills and } \\
\text { knowledge. }\end{array}$ & $\begin{array}{l}\text { Implement learnt home eco- } \\
\text { nomics ideology, pedagogy, } \\
\text { assessment and strategies in } \\
\text { classrooms. }\end{array}$ \\
\hline $\begin{array}{l}\text { Deliver professional develop- } \\
\text { ment workshops external to unit } \\
\text { content. }\end{array}$ & $\begin{array}{l}\text { Learning materials and } \\
\text { assessment explicitly use } \\
\text { home economics ideol- }\end{array}$ & $\begin{array}{l}\text { Convey public expressions } \\
\text { of home economics in action } \\
\text { through their own developed } \\
\text { pedagogical and ideological }\end{array}$ \\
\hline $\begin{array}{l}\text { Participate in scholarship activities } \\
\text { and advocacy beyond the profes- }\end{array}$ & $\begin{array}{l}\text { ogy to scaffold learning } \\
\text { activities. }\end{array}$ & lens. \\
\hline $\begin{array}{l}\text { Remain active on social media and } \\
\text { share positive home economics }\end{array}$ & $\begin{array}{l}\text { Encourage student par- } \\
\text { ticipation in association } \\
\text { activities and events. }\end{array}$ & $\begin{array}{l}\text { Participate independently in } \\
\text { home economics associations } \\
\text { and committees. }\end{array}$ \\
\hline stories. & Facilitate student use of & $\begin{array}{l}\text { Advocate for home econom- } \\
\text { ics education in public and }\end{array}$ \\
\hline $\begin{array}{l}\text { Display visceral and authentic } \\
\text { enthusiasm and passion for the } \\
\text { discipline. }\end{array}$ & $\begin{array}{l}\text { social media in ethical } \\
\text { ways to advocate for home } \\
\text { economics. }\end{array}$ & $\begin{array}{l}\text { political arenas (schools, } \\
\text { social media, awards, media, } \\
\text { school newsletters, conference } \\
\text { presentations). }\end{array}$ \\
\hline $\begin{array}{l}\text { Use positive language to cham- } \\
\text { pion home economics with new } \\
\text { to field professionals, existing } \\
\text { professionals and people external } \\
\text { to the field. }\end{array}$ & $\begin{array}{l}\text { Showcase student work } \\
\text { beyond the field at events } \\
\text { and in the media. }\end{array}$ & $\begin{array}{l}\text { Enrol in Research Higher } \\
\text { Degree Programmes and study } \\
\text { home economics explicit and } \\
\text { specific projects. }\end{array}$ \\
\hline
\end{tabular}


Explicit and frequent discussion with new-to-the-field professionals about the ideology of home economics reinforces connections between skills and knowledge learnt and broader health and wellbeing themes. To support lecturer actions, the provision of home economics literature has recently become more available, as gaps in research specific to home economics are being filled. Through concentrated efforts from home economics academics in numerous countries, research is becoming more available in university library databases and open access journals. Of note is the International Journal of Home Economics (IJHE), which is accessible through the IFHE website and Informit database. A simple university library database search engine was used to search the key term 'home economics', which revealed an increase in the publication of peer-reviewed journal articles for the decades 1990-2000 (364), 2001-2010 (657), and 2011-2020 (1,341). There is a long way to go to realising a saturation of literature in the field. Regardless, where new literature becomes available, it should be incorporated into curriculum and learning activities.

\section{Home economics contributions to purpose and passion}

Home economists can adjust their skills and knowledge to the requirements of their context by undertaking further study or upskilling professional development. Home economists are sometimes described as 'passionate' people (Nickols, 2001; Sewell, 2008). Formally trained home economists, because of their passion, generally, make a sustained commitment to the core ideology of home economics (Benn, 2010; Brown, 1993; Deagon, 2015b; Deagon \& Pendergast, 2014; Dewhurst \& Pendergast, 2011; Gentzler, 2012; Henry, 1995; Nickols-Richardson, 2001; Pendergast, 2013; Smith \& de Zwart, 2010; Turkki, 2012; Wahlen et al., 2009). Mechanisms for identifying locally relevant challenges faced by individuals, families, and communities are an embedded aspect of the home economics knowledge base. To identify these challenges (who, what, when, where, how and why), home economics education programmes must actively teach (or provide explicit instruction) about the ideology that underpins the Home Economics profession.

Home economics education contributes to students learning about their home environments and contributing to preparations for future career paths. Pertinent examples of individuals locating their passions through home economics education are reported in newspapers and research articles (Deagon, 2012; Gagne-Collard, 2002; Nickols, 2001; Sewell, 2008). To illustrate, a home economics class was identified as the catalyst for a teenager training to be a swimming athlete to initially become interested in learning how to cook for 
himself so he could ensure his energy and nutrition needs were suitable for his level of sporting activity. Once retired from his elite athlete status, he launched a restaurant (Deagon, 2012). Food and cooking became this individual's passion, and that passion was first realised in secondary school with the help of his home economics teacher.

The impact of a home economics teacher's passion can make a significant difference to a student's perceptions of home economics. To illustrate, persistent and consistent teaching that explicitly instructs the connections between content and ideology, one new-to-the-field professional commented in a recent media release:

Home Economics plays a really important role in special education, and teaching inclusivity to the next generation - because it's all about understanding people's needs, and addressing those needs. Home Economics, psychology and special education all just fit so perfectly together, and in the classroom they mean that teachers can impart vital life knowledge and skills in a fun way, and also a really practical way, which is the basis of inclusion for any gender or learning ability, and for every age and every culture. [My home economics lecturer] gave me the confidence to express what I had previously had trouble expressing... I'm usually a really quiet person, and [my lecturer] gave me my teacher voice ('Brisbane chef using home economics education to serve up unique path to inclusion', 2021).

Mechanisms for identifying locally relevant challenges faced by individuals, families, and communities are an embedded aspect of the home economics knowledge base. However, this selection of content and learning materials is usually driven by the individual lecturer of a course. A lecturer's exposure to the most recent best practices will determine how much ideology new-to-the-field professionals are exposed to. Decisions are made each term to update, include or omit certain knowledge from a course of study. As a curriculum development activity, unit course renewal will also mean adjustments to research and literature in the field. As a real-time problem occurs, home economics content and ideology adapt to societal needs. Pendergast and Deagon (2021) presented 14 peer-reviewed papers that are examples of how quickly home economics education and home economists responded to the global pandemic. For example, basic sewing skills are central skills and knowledge - learning a new pattern is a natural action. To this end, at the start of the pandemic, home economics-related social media was quickly saturated with photographs of students and home economists making masks for their families, neighbours and neighbourhoods. 
In effect, a problem was identified (urgent supply of face masks), and home economists quickly acted (made masks), which contributed to a locally relevant solution.

\section{Respect the term 'home economics' and acknowledge the ideology}

To identify the challenges of who, what, when, when, where and how, home economics education programmes must actively teach or provide explicit instruction about the ideology that underpins the Home Economics disciplinary field. As previously outlined, explicit instruction is a teaching model that demonstrates to students and new-to-the-field professionals what to do and how to do it. Ideology focuses the why, when, where and who of a discipline. Previous research revealed that without ideology or philosophy to underpin a disciplinary field, content is just content with no direction or purpose (Deagon, 2015a). Arguments for removing or changing the term 'home economics' are problematic in this regard (Stage, 2018). If the term is removed, in effect, the known and recognised ideology is also removed.

To illustrate the impact of removing the term 'home economics' from curricula, in Australia in 2019, the senior secondary schooling home economics syllabus was phased out and replaced with syllabi that separated discipline content knowledge. Senior secondary school students (typically aged between 15 and 18 years) can no longer study 'home economics' in its intended holistic form, which included an overarching rationale to 'achieve optimal and sustainable health and wellbeing for individuals, families and communities' (IFHE, 2008); rather, students now elect to study 'fashion design' or 'food and nutrition' in the senior phase of learning. The flow-on effect of discontinuing the Senior Syllabus is that study of home economics ideology was also removed from the Senior Curriculum and therefore not prioritised by some universities that now offer 'food and nutrition' or 'food technology' as separate teaching specialisations. This separation of the content may have destructive effects on the profession in the longer term.

As Christensen (2019) highlights, the home economics profession is not without internal and external struggles, and it is unrealistic to 'glorify' the home economics profession and not leave the significant challenges we face unacknowledged. Indeed, almost all disciplines joust for position in the curriculum (Luke et al., 2008). In Australia, mathematics and English are the two compulsory subjects that all students must take in some form where national testing data is collected. Every other subject beneath that hierarchy is in contestation in 
which varied importance is placed on each subject offered for study. The position of curriculum importance is often driven according to academic, societal, and industry needs of the time (Deagon, 2015a).

It seems that only when a discipline is acknowledged from outside of that discipline does it get noticed. Since the renowned (in home economics circles, at least) 'Bring Back Home Economics' article (Lichtenstein \& Ludwig, 2010), there has been a rise in public discourse that supports an elevated position of the subject in school curricula (Pendergast \& Deagon, 2021; Pendergast et al., 2013; Smith, 2016). In addition, there is an emerging trend of peer-reviewed studies that support home economics as relevant and useful in modern society (Cunningham-Sabo \& Simons, 2012) but mostly in relation to food literacy (Ronto et al., 2017b; Worsley et al., 2016). The profession is working toward contributions of evidence-based home economics research to support the field and practices. The profession requires funding support and acknowledgement to achieve this goal.

In summary, this section of the paper has highlighted the danger of neglecting ideology results in teaching unrelated subjects or compartmentalised content that have no connection to the core aims or the home economics 'big picture'. Respecting and understanding the term 'home economics' acknowledges the importance of the discipline's underpinning ideology and core aims and the profession's contribution to society.

\section{Visible and reinforced home economics ideology: the author's experience}

This paper has argued that equipped with the core ideology of the discipline, professionals that make visible to others the Home Economics 'big picture, or the why, are better equipped to enact real-world applications of home economics that can adapt continuously to meet ever-changing societal needs. To respond to this statement, this final section relates a more personal narrative about how I believe we need to make home economics ideology 'visible' and reinforced continuously across all content specialisation areas. This section draws from my experience and observations that by making home economics ideology 'visible' to my students, they acquired the words and concepts to explain to others the importance of the subject.

I identify as a home economist. The discontinuation of the Australian Home Economics senior syllabus was disappointing. Since entering academia in 2014, I have maintained my commitment to teaching new-to-the-field professionals about the history, ideology and philosophy of the home economics 
discipline. As stated above, home economics ideology has a clear and explicit focus of study - to achieve optimal and sustainable health and wellbeing of individuals, families and communities - and is embedded in the core discipline units that I am responsible for: food and textile technology; individuals, families and communities health and wellbeing; fashion design, and culinary science for teachers.

The university in which these events are occurring is the only university in that state that still explicitly names 'home economics' as a teaching specialisation. Through informal conversations, I have ascertained that new-to-the-field professionals were drawn to seek home economics as a teaching discipline either because they remembered it from their schooling and loved it or have experienced one of the many secondary schools in Australia with vibrant home economics departments. Australian home economics associations actively promote the subject on social media, through industry participation, professional development activities, and conferences. Therefore, the term 'home economics' is present and known, the content is present, but in the school curriculum, the discipline with its overarching ideology needs acknowledgement, funding, and revitalisation.

Despite changes to the curriculum, this paper has demonstrated that explicit instruction and embedded home economics ideology in a teacher education programme has had a positive impact on perceptions of the discipline across five years of cohorts of new-to-the-field professionals. As my peers did for me, my passion, knowledge, and expertise in the area have empowered the students to become stronger advocates for home economics. I make sure that my students are exposed to the latest literature in our field and hold frequent discussions about bigger concepts in the field. I ensure students are participating in learning activities that are authentic and genuine learning experiences and advocate for their active participation in the profession.

On a final note, I add my voice for people in positions of power to reorient the importance of home economics because the individuals, families, and communities of the world need to know vital life skills through the ideological, proactive and ever-changing home economics lens.

\section{Conclusion}

Home economics is forever changing and forever relevant (Gentzler, 2012). The global Covid-19 pandemic has highlighted the prevalence of relevant home economics skills, such as home cooking, face mask making, information and financial literacy, and strengthening family and community relationships (Pendergast \& Deagon, 2021). The core focus of home economics has not 
changed since its inception: optimal and sustainable living to support the health and wellbeing of individuals, families, and communities. When a higher education programme makes explicit the ideology of home economics, students become more confident in advocating for their discipline. Instilling in the new generation of home economics teachers the importance and relevance of their subject radiates into their communities where authorities who make decisions about budgets and contact teaching time also see the value in the discipline. We can position home economics to a higher priority through our words and actions (Deagon, 2012). Without the ideology to underpin all that we do and say, it is an unstable position from which to justify our contributions to education and society. Equipped with the explicit core ideology of the discipline, trained professionals make the home economics 'big picture' visible and, with more confidence, can enact real-world applications that adapt continuously to meet societal needs.

\section{References}

Ashman, G., Kalyuga, S., \& Sweller, J. (2020). Problem-solving or Explicit Instruction: Which should go first when element interactivity is high? Educational psychology review, 32(1), 229-247. https://doi. org/10.1007/s10648-019-09500-5

Benn, J. (2010). Home economics in development through action research. International Journal of Home Economics, 3(1), 2-19.

Brisbane chef using home economics education to serve up unique path to inclusion. (2021). CQUNINEWS. https://www.cqu.edu.au/cquninews/stories/general-category/2021-general/brisbanechef-using-home-economics-education-to-serve-up-unique-path-to-inclusion Brown, M. M. (1993). Philosophical studies of home economics in the United States: Basic ideas by which home economists understand themselves (Volume 3). Michigan State University.

Christensen, J. H. (2019). Blind spots of the self-glorification in home economics. International Journal of Home Economics, 12(2), 76-80. https://doi.org/https://search.informit.org/doi/10.3316/ informit.871935594378394

Cunningham-Sabo, L., \& Simons, A. (2012). Home economics: An old-fashioned answer to a modern-day dilemma? Nutrition Today (Annapolis), 47(3), 128-132. https://doi.org/10.1097/ NT.obo13e31825744a5

Darling, C. A., \& Turkki, K. (2009). Global family concerns and the role of family life education: An ecosystemic analysis. Family Relations, 58(1), 14-27. http://search.proquest.com.libraryproxy.griffith. edu.au/docview/213932701? accountid $=14543$

Deagon, J. R. (2012). Deaths, disasters and tasty treats: challenging public perceptions of home economics. In D. Pendergast, S. McGregor, \& K. Turkki (Eds.), The next 100 years - creating home economics futures (pp. 75-87). Australia Academic Press. 
Deagon, J. R. (2015a). Spiritual knowledges in Queensland curriculum documents: A framework for analysis. Curriculum Perspectives, 35(2), 16-29.

Deagon, J. R. (2015b). “Through the eyes of a satin bowerbird": A bricolage metaphor as an organising principle for a self-reflective process to explore spirituality in home economics contexts. Victorian Journal of Home Economics, 54(1), 7-21.

Deagon, J. R., \& Pendergast, D. (2014). Home economists' views and perceptions of spiritual health and wellbeing: A collective affirmation statement. Journal of the HEIA, 21(2), 2-12.

Dewhurst, Y., \& Pendergast, D. (2011). Teacher perceptions of the contribution of home economics to sustainable development education: a cross-cultural view. International Journal of Consumer Studies, 35(5), 569-577. https://doi.org/10.1111/j.1470-6431.2011.01029.x

Dislere, V., Pridane, A., Vronska, N., \& Lice-Zikmane, I. (2020). Development of home economics and technologies education in life quality in Latvia Latvia University of Life Sciences and Technologies, Faculty of Engineering, Institute of Education and Home Economics. Erjavšek, M., Lovšin Kozina, F., \& Kostanjevec, S. (2020). In-service home economics teachers' attitudes to the integration of sustainable topics in the home economics subject. CEPS journal, 11(1), 27-47. https://doi.org/10.26529/cepsj.614

Gagne-Collard, A. (2002). Celine Mathieu: A career based on reason and passion (Focus on people and programs / Regard sur les gens et les programmes). Canadian Home Economics Journal, 52(1), 41.

Gentzler, Y. S. (2012). Home economics: Ever timely and forever complex. Phi Kappa Phi Forum, 92(2), 4-7. http://search.proquest.com.libraryproxy.griffith.edu.au/docview/1020414791?account $\mathrm{id}=14543$

Graham, S., Graham, S., Gillespie, A., Gillespie, A., McKeown, D., \& McKeown, D. (2013). Writing: importance, development, and instruction. Reading \& Writing, 26(1), 1-15. https://doi.org/10.1007/ S11145-012-9395-2

Hall-Mills, S. S., \& Marante, L. M. (2020). Explicit text structure instruction supports expository text comprehension for adolescents with learning disabilities: A systematic review. Learning Disability Quarterly, 73194872090649. https://doi.org/10.1177/0731948720906490

Henry, M. (1995). Well-being, the focus of home economics: An Australian perspective [Doctoral dissertation]. University of New England.

IFHE (International Federation for Home Economics). (2008). Home Economics in the 21st century: position statement. http://www.ifhe.org/

Kruit, P. M., Oostdam, R. J., van den Berg, E., \& Schuitema, J. A. (2018). Effects of explicit instruction on the acquisition of students' science inquiry skills in grades 5 and 6 of primary education.

International Journal of Science Education, 4o(4), 421-441. https://doi.org/10.1080/09500693.2018.142 8777

Lichtenstein, A. H., \& Ludwig, D. S. (2010). Bring back home economics education. JAMA, 303(18), 1857-1858. https://doi.org/10.1001/jama.2010.592

Luke, A., Weir, K., \& Woods, A. (2008). Development of a set of principles to guide a P-12 syllabus 
framework. http://www.qsa.qld.edu.au

McCloat, A., \& Caraher, M. (2020). An international review of second-level food education curriculum policy. Cambridge Journal of Education, 50(3), 303-324. https://doi.org/10.1080/030576 4X.2019.1694641

McGregor, S. L. T. (2011). Home economics as an integrated, holistic system: Revisiting Bubolz and Sontag's 1988 human ecology approach. International Journal of Consumer Studies, 35(1), 26-34. https://doi.org/10.1111/j.1470-6431.2010.00920.x

Nickols-Richardson, S. M. (2001). Our collective soul. Journal of Family and Consumer Sciences, 93(3), 32-32. http://search.proquest.com.libraryproxy.griffith.edu.au/docview/218161910?account $\mathrm{id}=14543$

Nickols, S. Y. (2001). Keeping the Betty lamp burning. Journal of Family and Consumer Sciences, 93(3), 35-44. http://search.proquest.com.libraryproxy.griffith.edu.au/docview/218169914?account $\mathrm{id}=14543$

Nickols, S. Y., \& Kay, G. (2015). Remaking home economics: Resourcefulness and Innovation in changing times. University of Georgia Press.

Nickols, S. Y., Ralson, P. A., Anderson, C., Browne, L., Schroeder, G., Thomas, S., \& Wild, P. (2009).

The family and consumer sciences body of knowledge and the cultural kaleidoscope: Research opportunities and challenges. Family and Consumer Sciences Research Journal, 37(3), 266-283. https:// doi.org/10.1177/1077727Xo8329561

Nickols, S. Y., Turkki, K., Pichler, G., Kirjavainen, L., Atiles, J. H., \& Firebaugh, F. M. (2010). A Global perspective for FCS: Sustaining families, natural environments social capital. Journal of Family and Consumer Sciences, 102(4), 10-16.

Pendergast, D. (2013). An appetite for home economics literacy: Convergence, megatrends and big ideas. Journal of Asian Regional Association for Home Economics, 20(2), 57-65.

Pendergast, D., \& Deagon, J. (2021). Home economics, the COVID-19 global pandemic and beyond. International Journal of Home Economics, 14(1), 2-15.

Pendergast, D., Garvis, S., \& Kanasa, H. (2013). The value of home economics to address the obesity challenge: An evaluation of comments in an online forum. International Journal of Home Economics, 6(2), 272-285.

Ronto, R., Ball, L., Pendergast, D., \& Harris, N. (2017a). Environmental factors of food literacy in Australian high schools: views of home economics teachers. International Journal of Consumer Studies, 41(1), 19-27. https://doi.org/10.1111/ijcs.12309

Ronto, R., Ball, L., Pendergast, D., \& Harris, N. (2017b). What is the status of food literacy in Australian high schools? Perceptions of home economics teachers. Appetite, 108, 326-334. https://doi. org/10.1016/j.appet.2016.10.024

Sewell, D. T. (2008). Passion: A narrative journey to family and consumer sciences education (Order No. 3307064). Available from ProQuest One Academic. (230700160). https://ezproxy.cqu.edu. au/login?url=https://www.proquest.com/dissertations-theses/passion-narrative-journey-familyconsumer/docview $/ 230700160 /$ se-2 ?accountid $=10016$ 
Smith, G., \& de Zwart, M. (2010). Home Economics: A contextual study of the subject and home economics teacher education. http://www.thesa.ca/wordpress/wp-content/uploads/2016/o1/inquiry_ contextual.pdf

Smith, M. G. (2016). "Bring back home economics"? challenging contested discourses on obesity. Journal of Family and Consumer Sciences, 108(4), 7-12. https://doi.org/10.14307/JFCS108.4.7 Stage, S. (2018). Rethinking home economics: Women and the history of a profession. In S. Sarah \& B. V. Virginia (Eds.), Introduction home economics, what's in a name? (pp. 1-14). Cornell University Press. https://doi.org/doi:10.7591/9781501729942-003 Turkki, K. (2012). Home economics - a forum for global learning and responsible living. In D. Pendergast, S. McGregor, \& K. Turkki (Eds.), The next 100 years - creating home economics futures (pp. 38-51). Australia Academic Press. van de Kamp, M. T., Admiraal, W., van e, J., \& Rijlaarsdam, G. (2015). Enhancing divergent thinking in visual arts education: Effects of explicit instruction of meta-cognition. British Journal of Educational Psychology, 85(1), 47-58. https://doi.org/10.1111/bjep.12061

Wahlen, S., Posti-Ahokas, H., \& Collins, E. (2009). Linking the loop: Voicing dimensions of home economics. International Journal of Home Economics, 2(2), 32-47. http://search.informit.com.au/docu mentSummary; $\mathrm{dn}=721941138737452 ; \mathrm{res}=$ IELHSS

Worsley, A., Wang, W. C., Yeatman, H., Byrne, S., \& Wijayaratne, P. (2016). Does school health and home economics education influence adults' food knowledge? Health Promotion International, 31(4), 925-935. https://doi.org/10.1093/heapro/davo78

\section{Biographical note}

Jay R. Deagon, PhD, is a senior lecturer of home economics in the College of Education, School of Education and the Arts, Central Queensland University, Rockhampton, Australia. Her research interests include teaching and learning in home economics contexts, empowerment of marginalised people, and holistic health and wellbeing in educational settings. Jay's professional passions are initial teacher training, authentic assessment, service learning, and exploring home economics history, philosophy and ideology. 